\title{
Assessing Antibody Responses to Pathogens or Model Antigens in Xenopus by Enzyme-Linked Immunosorbent Assay (ELISA)
}

\author{
Francisco De Jesús Andino ${ }^{1}$ and Jacques Robert ${ }^{1}$ \\ Department of Microbiology and Immunology, University of Rochester Medical Center, Rochester, \\ New York 14642
}

Xenopus laevis-specific monoclonal antibodies recognize IgM and IgY antibodies not only from $X$. laevis but also X. tropicalis as well as a variety of amphibian species including Ranidae, Bufonidae, and even some salamanders. These reagents are very useful to assess antibody responses from the serum or other animal secretions (e.g., peritoneal fluid). We present here an enzyme-linked immunosorbent assay (ELISA) optimized for amphibians that permits users to detect and titrate the presence of each type of antibody (IgM and IgY) produced against particular pathogens (e.g., virus, bacteria, or fungus) or antigens (e.g., DNP-KLH).

Reagents

It is essential that you consult the appropriate Material Safety Data Sheets and your institution's Environmental Health and Safety Office for proper handling of equipment and hazardous materials used in this protocol.

Amphibian PBS (1× PBS diluted by adding 30\% v/v distilled water)

This is used only for injection in the amphibian recipient.

Blocking buffer $(1 \%$ BSA in $1 \times$ PBS)

ELISA substrate $\left(3,3^{\prime}, 5,5^{\prime}\right.$-tetramethylbenzidine [TMB])

Freund's adjuvant (optional; see Step 1)

$\mathrm{H}_{2} \mathrm{SO}_{4}(1 \mathrm{M})$

LB broth (optional; see Step 6)

Pathogen or antigen of choice (see preparation instructions in Steps 1 and 6):

Chytrid fungus (Batrachochytrium dendrobatidis) (Ramsey et al. 2010)

Dinitrophenylated keyhole limpet hemocyanin (DNP-KLH) (Du Pasquier et al. 1985)

Heat-killed E. coli bacteria (e.g., Stratagene XL-blue) (Robert et al. 2014)

Mycobacterium (Mycobacterium marinum) (Shirtcliffe et al. 2004)

Ranavirus (frog virus 3 [FV3]) (De Jesús-Andino et al. 2016)

PBS (10×, mammalian; e.g., OmniPur $10 \times$ PBS, premixed powder)

Dilute in $d \mathrm{dH}_{2} \mathrm{O}$, filter through $0.2-\mu \mathrm{m}$ sterile filter flask, and store at $4^{\circ} \mathrm{C}$.

PenStrep (Gibco 15070-063) or ethacridine lactate $(10 \mu \mathrm{g} / \mathrm{mL})$

\footnotetext{
${ }^{1}$ Correspondence: francisco_dejesus@urmc.rochester.edu; jacques_robert@urmc.rochester.edu From the Xenopus collection, edited by Hazel L. Sive.

(C) 2019 Cold Spring Harbor Laboratory Press

Cite this protocol as Cold Spring Harb Protoc; doi:10.1101/pdb.prot099234
} 
Secondary antibody (goat anti-mouse IgG-horseradish peroxidase conjugated [IgG-HRP])

Tricaine methane sulfonate (TMS; $0.1 \%$ or $1 \mathrm{~g} / \mathrm{L}$; Western Chemicals MS-222) buffered with $0.5 \mathrm{~g} / \mathrm{L}$ sodium bicarbonate (Fisher Scientific S-2333)

We use sodium bicarbonate to keep the $\mathrm{pH}$ of the final solution near the ambient environmental $\mathrm{pH}$ for Xenopus laevis.

Wash buffer ( $1 \times$ PBS containing $0.05 \%$ Tween 20$)$

To increase stringency, $1 \% \mathrm{BSA}$ as well as $1 \% \mathrm{NaCl}$ can be added.

Xenopus laevis adults

Xenopus laevis-specific antibodies (mouse monoclonal antibodies 11D5 (IgY) and 10A9 (IgM), which are available upon request from the Xenopus laevis Research Resource for Immunobiology [https:// www.urmc.rochester.edu/microbiology-immunology/xenopus-laevis.aspx])

Equipment

96-well plates (sterile, flat-bottomed, polystyrene)

Benchtop centrifuge (Beckman Coulter Allegra X-30R centrifuge)

Conical centrifuge tubes $(10-\mathrm{mL})$

Glass tubes are preferable for optimal blood coagulation.

ELISA reader instrument (SpectraMax M5 with Softmax Pro 6.4 software, optical system monochromator, and xenon flash lamp, with the fluorescence intensity at $420 \mathrm{~nm}$ and $25^{\circ} \mathrm{C}$ )

Needles (22G, 11/2 inch)

Pulled glass needle, sterile (Du Pasquier et al. 1985; Nedelkovska et al. 2010)

Syringes, sterile $(1-\mathrm{mL})$

METHOD

Immunization

1. Immunize frogs by intraperitoneal injection in the abdominal region using a $1 \mathrm{~mL}$ sterile syringe with a $22 \mathrm{G}, 1 \frac{1}{2}$ inch needle of the following pathogens or antigens diluted in amphibian PBS.

- Ranavirus FV3: $1 \times 10^{6}$ PFU in $100 \mu \mathrm{L}$ volume of amphibian PBS per adult frog; (Maniero et al. 2006).

- Mycobacterium marinum: $1 \times 10^{5} \mathrm{CFU}$ in $100 \mu \mathrm{L}$ volume of amphibian PBS per adult frog.

- Heat-killed E. coli: $100 \mu \mathrm{L}$ of $10^{8}$ bacteria/mL in amphibian PBS; (Robert et al. 2014) or Batrachochytrium dendrobatidis: $10 \mu \mathrm{L} / \mathrm{g}$ body weight of heat-killed B. dendrobatidis (mixed zoospores and maturing sporangia) at a concentration of $5 \times 10^{7}$ cells $/ \mathrm{mL}$ (Ramsey et al. 2010).

- DNP-KLH: doses can range from 2-10 $\mu \mathrm{g} / \mathrm{g}$ body weight emulsified in complete Freund's adjuvant (Du Pasquier et al. 1985)

2. After immunization with the pathogen or antigen, anesthetize frogs by immersion in a $0.1 \%$ tricaine methane sulfonate buffered with $0.5 \mathrm{~g} / \mathrm{L}$ sodium bicarbonate. Leave frogs in the TMS for up to $5 \mathrm{~min}$ or until all movement ceases.

3. Collect blood from the dorsal tarsus vein of adult Xenopus laevis using a sterile pulled glass needle as described (Du Pasquier et al. 1985; Nedelkovska et al. 2010). One to two mL of blood can be obtained from one average sized $(\sim 200 \mathrm{~g})$ frog. Collect the blood in a $10 \mathrm{~mL}$ conical glass centrifuge tube placed on ice. After bleeding, place the frog(s) in water containing an antiseptic $(2.5 \mathrm{~mL} / \mathrm{L}$ PenStrep or ethacridine lactate) for a day (Du Pasquier et al. 1985; Nedelkovska et al. 2010).

4. Let the blood coagulate overnight at $4^{\circ} \mathrm{C}$ in a tube closed with a cap. 
F. De Jesús Andino and J. Robert

5. In a benchtop centrifuge, centrifuge the blood for $15 \mathrm{~min}$ at $1000 \mathrm{~g}$ at $4^{\circ} \mathrm{C}$. Collect the serum (supernatant), and store at $-20^{\circ} \mathrm{C}$ until use.

\section{Antigen or Pathogen Absorption}

6. Dilute pathogen or antigen used to immunize frogs in $1 \times \mathrm{PBS} \mathrm{pH} 8.0$ unless otherwise noted (see below). Place $100 \mu \mathrm{L}$ of diluted antigen per well of a 96-well plate and incubate overnight at $4^{\circ} \mathrm{C}$.

The number of wells will depend of the number of assays you wish to perform. See Step 8 to plan appropriate controls.

- Ranavirus FV3: Grow and purify live FV3 from baby hamster kidney (BHK-21) cell lines incubated at $30^{\circ} \mathrm{C}$ for $5-6 \mathrm{~d}$ as previously described (De Jesús-Andino et al. 2016). Dilute virus ( 0.5 to $1 \times 10^{7} \mathrm{PFU}$ per well) in $100 \mu \mathrm{L} 1 \times \mathrm{PBS}$ (Maniero et al. 2006).

- Mycobacterium marinum $\left(1 \times 10^{2}\right.$ to $\left.1 \times 10^{7} \mathrm{CFU}\right)$ : Boil M. marinum for an hour and sonicate for $2 \mathrm{~min}$ (Shirtcliffe et al. 2004). Pellet M. marinum by centrifugation for $15 \mathrm{~min}$ at $3500 \mathrm{rpm}$ and resuspend in $1 \times$ PBS $+0.05 \%$ Tween 80 .

- E. coli: prepare an overnight culture in $25 \mathrm{~mL} \mathrm{LB}$ broth and incubate at $37^{\circ} \mathrm{C}$. Boil the culture for $1 \mathrm{~h}$ and centrifuge for $15 \mathrm{~min}$ at $3500 \mathrm{rpm}$ at $4^{\circ} \mathrm{C}$. Resuspend in $2.5 \mathrm{~mL}$ of $1 \times$ PBS $\left(\sim 10^{8}\right.$ bacteria/mL) (Robert et al. 2014).

- Batrachochytrium dendrobatidis (JEL 197): heat-kill for $20 \mathrm{~min}$ at $60^{\circ} \mathrm{C}$. Dilute fungus in $1 \times$ PBS with $\sim 5 \times 10^{4}$ cells per well (Ramsey et al. 2010).

- DNP-KLH: dilute in 1× PBS (1-10 $\mu \mathrm{g} / \mathrm{mL}$; Du Pasquier et al. 1985).

Blocking, Antibody Incubations, and Development

7. Remove solution from Step 6 from all wells and wash each well by adding $200 \mu \mathrm{L}$ of blocking buffer per well. Incubate for $10 \mathrm{~min}$ at room temperature and discard the supernatant. Perform this wash three times as described.

Unbound antigen/pathogen will be removed at this step.

8. Add $100 \mu \mathrm{L} /$ well of Xenopus (or other species) serum dilutions (2 to 3 dilutions between 1:501:1000) from immunized (Step 1) and naïve animals. Use the following dilutions: viral infection: 1:50 to 1:200 dilutions; bacterial immunization: 1:100 to 1:1000 dilutions; fungal immunization: 1:100 to 1:1000 dilutions; or DNP-KLH immunization: $1: 100$ to $1: 1000$ dilutions in blocking buffer. Each sample should be tested in triplicate. It also very important to always coat with negative and positive controls (note that all wells will be coated with antigen from Step 6).

- Negative controls can include: (i) normal nonimmunized Xenopus serum; and/or (ii) PBS containing $1 \%$ bovine serum albumin (BSA).

- Positive controls can include: (i) an antiserum known to contain antibodies, serving as a control for the binding of the Xenopus-specific secondary monoclonal antibody; (ii) the secondary mAbs (10A9 or 11D5) serving as control for the binding and signal of tertiary HRP-conjugated goat anti-mouse antibody.

- Specificity controls coated with the antigen (pathogen or DNP-KLH) but without antiserum (i) or without secondary mAbs (ii).

9. Incubate $1-3 \mathrm{~h}$ at room temperature or overnight at $4^{\circ} \mathrm{C}$.

10. Remove the extra serum. Wash each well $5 \times$ for $10 \mathrm{~min}$ each wash with $100 \mu \mathrm{L}$ wash buffer at room temperature.

11. Add $100 \mu \mathrm{L} /$ well of 11D5 (to detect antigen-specific IgY) supernatant or 10A9 (to detect antigenspecific IgM) supernatant containing $50-100 \mu \mathrm{g} / \mathrm{mL}$ of the primary antibody diluted $2 \times$ in blocking buffer. Incubate for $2 \mathrm{~h}$ at room temperature or overnight at $4^{\circ} \mathrm{C}$. 
12. Remove the unbound or extra supernatant. Wash each well $5 \times$ for 10 min each wash with $100 \mu \mathrm{L}$ wash buffer at room temperature.

13. Add $100 \mu \mathrm{L} /$ well of the goat anti-mouse IgG-HRP diluted 1:5000 in blocking buffer. Incubate for $1 \mathrm{~h}$ at room temperature.

14. Wash each well 6 to $8 \times$ with $100 \mu \mathrm{L}$ wash buffer for $10 \mathrm{~min}$ each wash at room temperature.

15. Incubate each well with $100 \mu \mathrm{L}$ of 1 Step Ultra TMB for 30-60 min at room temperature.

16. Block and incubate reaction with $100 \mu \mathrm{L}$ of $1 \mathrm{M} \mathrm{H}_{2} \mathrm{SO}_{4}$ for $\sim 5 \mathrm{~min}$. Read plates at $420 \mathrm{~nm}$. (The different reagents used and steps are depicited in Fig. 1.)

See Troubleshooting.

Problem (Step 16): There is too much background (e.g., signal detected in negative control).

Solution: Increase the stringency of the washes by increasing the molarity of the $\mathrm{NaCl}$ and/or by increasing the percent of detergent.

Problem (Step 16): No signal upon plate reading.

Solution: The different controls should permit users to determine whether secondary or tertiary antibody is working.

ELISA provides a reliable and very sensitive method to monitor an immune response. Since blood samples can be collected multiple times from the same animal, it is an ideal technique to determine the kinetics of an immune response. When planning to incorporate an ELISA in any experiments there are some aspects important to consider.
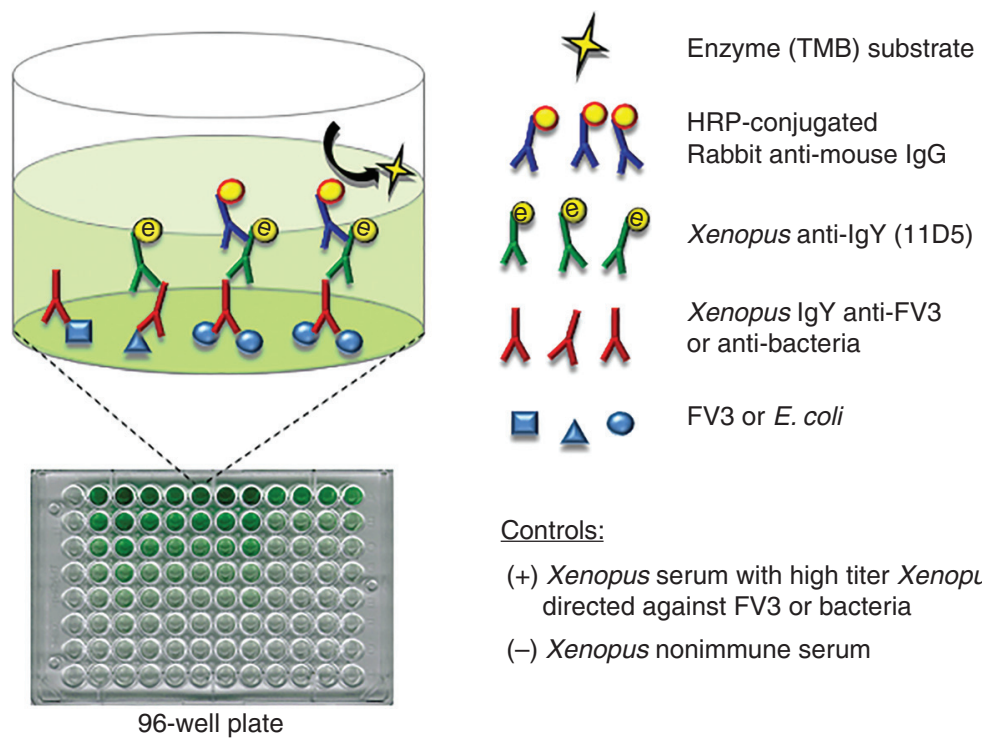

Controls:

(+) Xenopus serum with high titer Xenopus Ab directed against $\mathrm{FV} 3$ or bacteria

(-) Xenopus nonimmune serum

FIGURE 1. Schematic of ELISA depicting the different reagents added sequentially into a culture well of a 96-well flatbottom plates. The sequential addition of reagents is listed from bottom to top on the right. 
Type of ELISA, Plates and Consistency

They are four general types of ELISAs: direct (using labeled primary antibody), indirect (involving two binding processes of primary antibody and labeled secondary antibody), sandwich (quantifying antigens between two layers of antibodies, a capture and detection antibody), and competitive (using a second antigen to compete and determine the binding specificity). The type of ELISA used for a particular experiment will depend on multiple factors including the complexity of the experimental samples, the reagents or antibodies available (e.g.) availability of a secondary antibody directed against the primary antibody) and the level of sensitivity required (e.g., indirect and sandwich ELISA are more sensitive than direct ELISA because the binding of secondary and tertiary antibodies to additional targets will enhance the signal.

One of the most common plates used for ELISA assays is the flat-bottomed, 96-well polystyrene plate based on its consistency, minimizing edge effects (e.g., overlap toward the outer edges of the well during the analysis, more uniform cell layer compared to the round-bottomed plates) and giving optimal optical conditions for the data collection.

Using multiwell plates, multichannel pipettes, and reservoirs (plate washers) will provide a high consistency and faster results. Improperly calibrated or dirty pipettes will cause cross contamination in your samples, resulting in variation in your results. Also, it is important to make sure that the levels of the samples in your multichannel pipette match, as sometimes tips are not well-attached to the pipette, which will affect your results.

Antisera

Blood coagulation can be influenced by the type of tube used. Conical glass tubes are the most suitable for blood coagulation. However, plastic tubes can be used.

Secondary Antibodies

They are usually two types of secondary antibodies used for ELISA: monoclonal and polyclonal antibodies. Because a monoclonal antibody recognizes a single epitope it is more specific but if it cross-reacts nonspecifically with proteins in the assay, it can be challenging to reduce this nonspecific binding. Monoclonal antibodies are more likely than polyclonal antibodies to contain a fraction of nonspecific cross-reacting antibodies. However, this nonspecific background can usually be reduced by diluting the antibody. It also possible to absorb the antibody on cells (e.g., erythrocytes, splenocytes) from the species from which the sample tested originates before using it for this assay. It is also important to test samples in duplicate or triplicate including known standards (positive and negative controls) and to test several dilutions for optimal results and quantitation.

\section{Coating, Washing, and Blocking Buffers}

For coating the antigen, buffer controlling the $\mathrm{pH}$ such as $\mathrm{PBS}$ or Tris- $\mathrm{HCl}$ containing $1 \% \mathrm{NaCl}$ are preferred. A slightly basic $\mathrm{pH}(8.0)$ is usually optimal for the maximal binding of antigens. The blocking buffer is important to prevent nonspecific binding of the antibodies used, especially against the plastic wall of the multiwell plate itself. This can affect the sensitivity of the assay (nonspecific signal) detected by the ELISA instrument. In addition to blocking, it is very important to wash extensively between each step of the ELISA. Wash buffer should be the same PBS or Tris- $\mathrm{HCl}$ saline type containing a nonionic detergent such as Tween 20 to prevent binding by the negative electric charges of the antibodies. The wash buffer is used to remove nonbound reagents, decreasing background and enhancing specific signal. It is recommended to wash at least 3-5 times between each step, but more wash cycles can be added to decrease the background. The small amounts of the retained buffer in the multiwell plate should be removed to prevent dilution of the reagents used. This can be done by careful aspiration or tapping the plate upside down on an absorbent paper. Insufficient or excessive washing may lead to high background signal or decreased sensitivity, respectively. 


\section{REFERENCES}

Du Pasquier L, Flajnik M, Guiet C, Hsu E. 1985. Methods used to study the immune system of Xenopus. Immunol Methods 3: 425-464.

De Jesús-Andino F, Letitia L, Maggirwar S, Robert J. 2016. Frog Virus 3 dissemination in the brain of tadpoles, but not in adult Xenopus, involves blood brain barrier dysfunction. Sci Rep 6: 22508 .

Maniero G, Morales H, Gantress J, Robert J. 2006. Generation of a longlasting, protective, and neutralizing antibody response to the ranavirus FV3 by the frog Xenopus. Dev Comp Immunol 30: 649-657.

Nedelkovska H, Cruz-Luna T, McPherson P, Robert J. 2010. Comparative in vivo study of gp96 adjuvanticity in the frog Xenopus laevis. J Vis 16: 2026
Ramsey JP, Reinert LK, Harper LK, Woodhams DC, Rollins-Smith LA. 2010 Immune defenses against Batrachochytrium dendrobatidis, a fungus linked to global amphibian declines, in the South African clawed frog, Xenopus laevis. Infect Immunol 78: 3981-3992.

Robert J, Grayfer L, Edholm ES, Ward B, De De Jesús-Andino F. 2014. Inflammation-induced reactivation of the ranavirus Frog Virus 3 in asymptomatic Xenopus laevis. PLoS One 9: e112904.

Shirtcliffe PM, Easthope SE, Weatherall M, Beasley R. 2004. Effect of repeated intradermal injections of heat-inactivated Mycrobacterium bovis Bacillus Calmette-Guerin in adult asthma. Clin Exp Allergy 34: 207-212. 


\section{Assessing Antibody Responses to Pathogens or Model Antigens in Xenopus by Enzyme-Linked Immunosorbent Assay (ELISA)}

Francisco De Jesús Andino and Jacques Robert

Cold Spring Harb Protoc; doi: 10.1101/pdb.prot099234 originally published online July 24, 2018

\begin{tabular}{|c|c|}
\hline $\begin{array}{r}\text { Email Alerting } \\
\text { Service }\end{array}$ & Receive free email alerts when new articles cite this article - click here. \\
\hline $\begin{array}{l}\text { Subject } \\
\text { Categories }\end{array}$ & $\begin{array}{l}\text { Browse articles on similar topics from Cold Spring Harbor Protocols. } \\
\text { Antibodies (119 articles) } \\
\text { Antibodies, general (289 articles) } \\
\text { Cell Biology, general (1382 articles) } \\
\text { Immunoassay (26 articles) } \\
\text { Immunodetection ( } 34 \text { articles) } \\
\text { Immunology, general (128 articles) } \\
\text { Xenopus (210 articles) }\end{array}$ \\
\hline
\end{tabular}

